\title{
FACTORS INFLUENCING A CUSTOMER-SERVICE CULTURE IN A HIGHER EDUCATION ENVIRONMENT
}

\author{
JACQUES LIEBENBERG \\ NEIL BARNES \\ Department of Human Resource Management \\ Rand Afrikaans University
}

\begin{abstract}
The higher education environment is experiencing significant changes, and the focus is moving to competitiveness and customer care. The role of organisational culture and job satisfaction in the delivery of quality customer service was investigated in this study. The indications are that a relationship should exist between organisational culture and learner satisfaction, but it transpired that the relationship between staff members' job satisfaction and learner satisfaction was not significant. An evaluation of a proposed learner-satisfaction model revealed interesting dynamics influencing relationships between the core dimensions studied.
\end{abstract}

\section{OPSOMMING}

Die hoëronderwysomgewing is besig om betekenisvol te verander, en die fokus is besig om na mededingendheid en kliëntesorg te verskuif. Die rol van organisasiekultuur en werksbevrediging in die lewering van hoëgehaltekliëntediens is in hierdie studie ondersoek. Daar is aanduidings dat daar 'n verband tussen organisasiekultuur en leerdertevredenheid is, maar dit het geblyk dat daar nie 'n betekenisvolle verband tussen werksbevrediging en leerdertevredenheid is nie. 'n Evaluering van 'n voorgestelde leerdertevredenheidsmodel het interessante dinamika wat die verhouding tussen die kerndimensies van die studie beïnvloed, aan die lig gebring.

If one could spend some time in the environment in which higher education institutions function, it would be quite clear that the relatively calm waters of a few years ago are becoming more stormy. In an attempt to transform and streamline the higher education system, the Minister of Education, Professor Kader Asmal, has embarked on a process that will see a reduction in the number of higher education institutions in South Arica. A number of the universities and technikons will merge, leaving a smaller number of institutions to render the service to the learners in South Africa.

In addition to the vision of the Minister of Education, more and more privately owned institutions, and institutions from the international arena, are seeking business opportunities and ways of extending their market share in South Africa (Annual Report of the CHE, 1999). In a recent survey conducted by the Human Sciences Research Council (HSRC), the factors that affect learners' choice with regard to higher education were investigated (Cosser \& Du Toit, 2002). One of the factors that was assessed was whether or not learners would like to continue their studies at private or public institutions. It is interesting to note that $9,6 \%$ of the learners intended to continue with their studies at private institutions (Cosser \& Du Toit, 2002). In terms of the total number of learners furthering their studies, it may not seem to be such a high figure, but its significance lies in the fact that learners are considering private institutions above the public institutions. One wonders whether this figure will increase in the future. If that is the case, then it will be an indictment against the higher education institutions in South Africa, for not being able to render the required service that the customer (learner) seeks.

Some of the reasons for this decision by the learners is that the private institutions will prepare them better for the labour market, have better reputations in their field of study, and better reputations than the public institutions (Cosser \& Du Toit, 2002, p. 5).

The competition is, however, not limited to the "outsiders". Amongst the traditional institutions, the competition is strong. When visiting the various websites, such as those of Stellenbosch University and Potchefstroom University, it is clear that there is a concentrated focus on branding and marketing those

Requests for copies should be addressed to: I Liebenberg, Department of Human Resource Management, RAU, PO Box 524, Auckland Park, 2006 institutions. The radio is also used as a medium for marketing and for reaching potential customers for the next academic year.

This means that the market share of the public institutions is being reduced or at least competed for. With the unlimited possibilities of the information era (Peters, 2002) and free access through the Internet, students are now in a position to continue their studies at any institution in the world, without leaving their own homes. This development is making the business of higher education extremely competitive.

The Higher Education Act, 1997 (Act No. 101 of 1997), made provision for the establishment of the Council on Higher Education (CHE). In terms of this Act, the Council on Higher Education (CHE) is a statutory body that provides independent, strategic advice to the Minister of Education on matters relating to the transformation and development of higher education in South Africa. This will include the management of quality assurance and quality promotion in the higher education sector. The $\mathrm{CHE}$ arranges and coordinates conferences, publishes information regarding developments in higher education, including an annual report on the state of higher education, and promotes the access of learners to higher education institutions.

The focus of the CHE is therefore the promotion of quality in higher education. This is not a unique situation, since there are many other countries in the world that have these types of structures in place. For example, promotional activities are well established and common in higher education institutions in Great Britain (Annual Report, CHE, 1999). It would even be safe to say the concept may have been borrowed from them. Although the focus is, for the moment, on the quality of academic programmes and the accreditation of the various institutions' programmes, there must be room for better service delivery to the customer (in this case, the customers are predominantly learners, but also include the employers in the country and the broader society).

It would also be fair to argue that quality is not only limited to the content of the academic programmes, the nature and the level of research or the number of articles published by the institution. Quality also relates to the levels of service that the customer receives. Cheales (1994) refers to King and the concept of excellent service. According to King, excellent service is a 
judicious blend of factors; the main one being added value. The suggestion here is that if one wants customers to come back for more, you have to reward them. You must give them something they will not find elsewhere.

Cheales (1994, p. 4) makes the point that "the vital elements of [product] quality, namely design, welding expertise, paint application, manufacturing technique and fine attention, no longer provide the competitive edge ..." . According to him, the competitive advantage is in the overriding philosophy that the customer is the first priority, since, if the customer does not return, one does not have a reason to continue with one's activities.

The question is, however, whether any of this relates to the sector of higher education. The answer is affirmative the CHE has the mammoth task of ensuring quality in higher education, but, apart from that, is there another reason why the higher education sector should have this debate? Slabbert, Prinsloo, Swanepoel and Backer (1998) argue that organisations must be mindful of the environment where they function, promote their business, or render any services. The authors see the environment as "... the aggregate of all conditions, events and influences that surround and affect it".

In the survey conducted by the HSRC, interesting information was gathered on preferred institutions for continued learning. To a certain extent, this could be seen as the potential market share the various institutions have, compared to the rest of the sector. According to the results of the survey, $16,6 \%$ of the learners indicated Technikon Pretoria as first choice where they would like to continue their studies. The closest competitor was Technikon Witwatersrand with 4,9\% (Cosser $\&$ Du Toit, 2002). Cosser \& Du Toit are of the opinion that the reason for this is the perception of customers that quality products and services are delivered. According to the survey, the most important factor influencing the choice of institution is the reputation of the institution, and the reputation of the school, faculty or department recommended by a friend. Although there are other factors, such as fees, sport facilities, accommodation and the alma mater of relatives, which influence the choice, it is clear that what the institution offers in terms of quality and the total package is of paramount importance.

It would, therefore, be reasonable to argue that the higher education sector in South Africa will increasingly be forced to conduct its business in a manner similar to that of its private sector neighbours in order to survive and retain its market share. In order to succeed, more attention should be paid to the customer.

In addition to the above, key environmental variables can be identified at both an external and an internal level. At the external level, the variables are listed as the increased levels of competition by both the local and international public institutions, the increase in the competition by private institutions, the changing policy of the new government with regard to the higher education environment and its attempts to ensure quality, which will be the task of the CHE, and access to higher education for all South Africans.

At the internal level, the internal programmes to promote quality in the organisation in terms of processes and procedures, the quality of the academic programmes, service delivery to learners, service delivery to employees in the execution of their task, and the sport and accommodation facilities are all aspects that should contribute to the promotion of the customer service and will impact on an institution's ability to compete effectively.

Before one embarks on a study of this nature, the need for the study should be established. As indicated in the introduction, the environment of higher education is dramatically, changing. Higher education institutions will have to come to terms with the fact that they have to be competitive. If they are not successful, their very existence may be in the balance. The vision of the Minister of Education is a clear signal of what the expectation for higher education institutions is.

In future, there will be more and more pressure on institutions to become world-class and competitive, and to facilitate an effective educational process that will deliver the high-quality manpower that will meet the needs of the South African labour market. If higher education institutions are not successful in this area, they will lose their market share. The question will be: Why do we keep these institutions if they do not meet the expectations? The biggest contribution an institution can make towards the economic growth and social upliftment of South Africa is to deliver highquality manpower.

Underpinning this total effort is the level of customer service that is rendered to the client, and, more specifically, the learner. Quality customer service is one of the fundamental elements of being world-class, and one of the major elements that influence quality customer service may be the culture of an organisation. It could therefore be argued that those elements (customer service and culture) should be studied in the context of the higher education environment in order to develop a strategy that could assist in meeting the expectations set for higher education institutions.

\section{Current level of knowledge of the problem}

In the following section, attention will be given to the current level of knowledge with regard to the problem. In addressing this problem there are essentially three elements that stand out. The first is customer care or service, the second is the corporate culture that exists within the organisation, and the third is job satisfaction of staff members.

Customer care and its relevance

At the beginning of this article, the point was argued that there is a link to be found in the levels of customer care and market share. Admittedly the information that was cited in the introduction does not necessarily represent all possible elements that may influence the choice of students. It does however, give an indication of the basic thinking in this regard and does warrant further investigation. In this section the focus will be on the relevance and importance of customer care.

Gitomer (1998, p. 45) is of the opinion that the challenge for the 21 st century is not just serving the customers "... it is understanding the customer, being prepared to serve customers, helping an angry customer immediately, asking the customer for information, listening to customers, being responsible for your actions when a customer calls, living up to your commitments, being memorable, surprising customers, striving to keep customers for life and getting unsolicited referrals from customers ... regularly." He feels strongly that the focus should not only be on delivering a good service to the customer, but also to generate loyalty in the customer so that the customer would continue to do business with the organisation.

One should ask the question "why is good customer care so important?" To be competitive and successful in the globalised world, where the information era forms part of reality, requires that an organisation functions at a level that can be regarded as world-class. According to Hodgetts, Luthaus \& Lu (1994) and Belohov (1996), being worldclass should be regarded as a prerequisite for being successful in a globalised market. 
In support of the argument, maybe more in a South African context, Slabbert et al. (1998) argue that “... if we don't succeed in making our organisation more competitive in the international arena, in becoming 'world-class', there are very few chances of creating meaningful job opportunities and of escaping the path towards social-economic decay and eventually becoming 'just another lost African Country'." Although this represents a harsh perspective, it is a true reflection of the realities that a country such as South Africa is faced with. In order to be successful in the international economy, an organisation should be world-class.

What, however, is the definition of a world-class organisation? Hodgetts et al. (1994:1) define a world-class organisation as "... the best in its class or better than its competitors around the world at least in several strategically important areas." Therefore, a world-class organisation is an organisation that is not only the best, but also remains ahead of its competitors. Hodgetts et al. (1994) point out a variety of characteristics that are to be found in all world-class organisations. The characteristics of a world-class organisation can be summarised as follows (Steudel \& Desruelle, 1991, pp. 3-8) and (Olson 1990, pp. 6-19):

- customer-care-driven

- leadership/visionary leadership

- participation

- some type of remuneration system

- prevention rather than correction

- a long-term focus

- partnership development

- a new culture of thoughts and goals

- worker participation and people development

- shared values

- performance evaluation

- flatter organisational structures

Although Hodgetts et al. (1994), supported by Steudel \& Desruelle (1991, pp. 3-8) and Olson (1990, pp. 6-19), list various characteristics of a world-class organisation, the characteristic that stands out is the aspect of customer care. Dannhauser \& Roodt (2001, p. 8) are of the opinion that: "In the present highly competitive and global market-environment, an increased emphasis is placed on organisations to adopt a new corporate paradigm, i.e. a value orientation towards delivering total quality customer service". This notion is supported by Tersine, Harvey and Buckley (1997, p. 47). They are of the opinion that the "... global market has brought about a renewed emphasis on the customer as being the focal point of business activities. In a buyer's market, being customer-centric is paramount". Therefore, it can be argued that the ability of an organisation to deliver a high-quality customer service is a requirement for being regarded as world-class and competing effectively in the global market.

From the above it is clear that good customer service is a requirement for any organisation today. It is, however, easy and simple to say what needs to be done, but the question is "How is it done?" and "What are the things you need to do to get the desired effect?". There must a model that can be used to guide us and lead the way. Obviously it is not a matter of following a "ten steps to success" situation.

Heskett, Jones, Loveman, Sasser and Schlesinger (1994) provide a model in the form of the "service-profit chain" (see Figure 1). According to them, this model provides a framework that can be used to operationalise the strategies that will enhance the current levels of customer care to a level equal to that of meeting the world-class demands.

\section{Employee satisfaction}

The Service-Profit Chain deals with a variety of issues, the main ingredients being customer and employee satisfaction. Because of the very nature of the concept of customer care, customer care is not something that can be delivered or provided by machines. Technology may enhance the process and assist in the delivery of better customer care, but, ultimately, customer care is delivered by people.

The people's behaviour in the organisation must enforce the values of the organisation (Gubman, 1995, p.16). Tersine et al. (1997, pp. 46-49) take this line of thought a step further in arguing that the behaviour of the people within the organisation should not just only enforce the value, but rather that an organisational culture should be established that can act as the driving force behind the customer care.

Pete Peterson, Vice-President of Human Resources of HewlettPackard, supports this notion: "Everyone will tell you that people are important, but we put our words into action. Good people management is the very key to our overall environment. We believe that if we hire topnotch, creative, dedicated people and if we provide the proper environment, they will succeed" (Verespay, 1990, p.23). Therefore, if you want to succeed as an organisation, you need the best people and you need to create an environment that will make them want to stay and an environment that is conducive to productivity and performance. Grant-Marshall (2002), underpins this principle in more detail. She is of the opinion that "... smart companies are the ones who are making workplaces great places". This comment is based on the Financial Mail's Top 100 companies and other best companies to work for. In the article concerned,

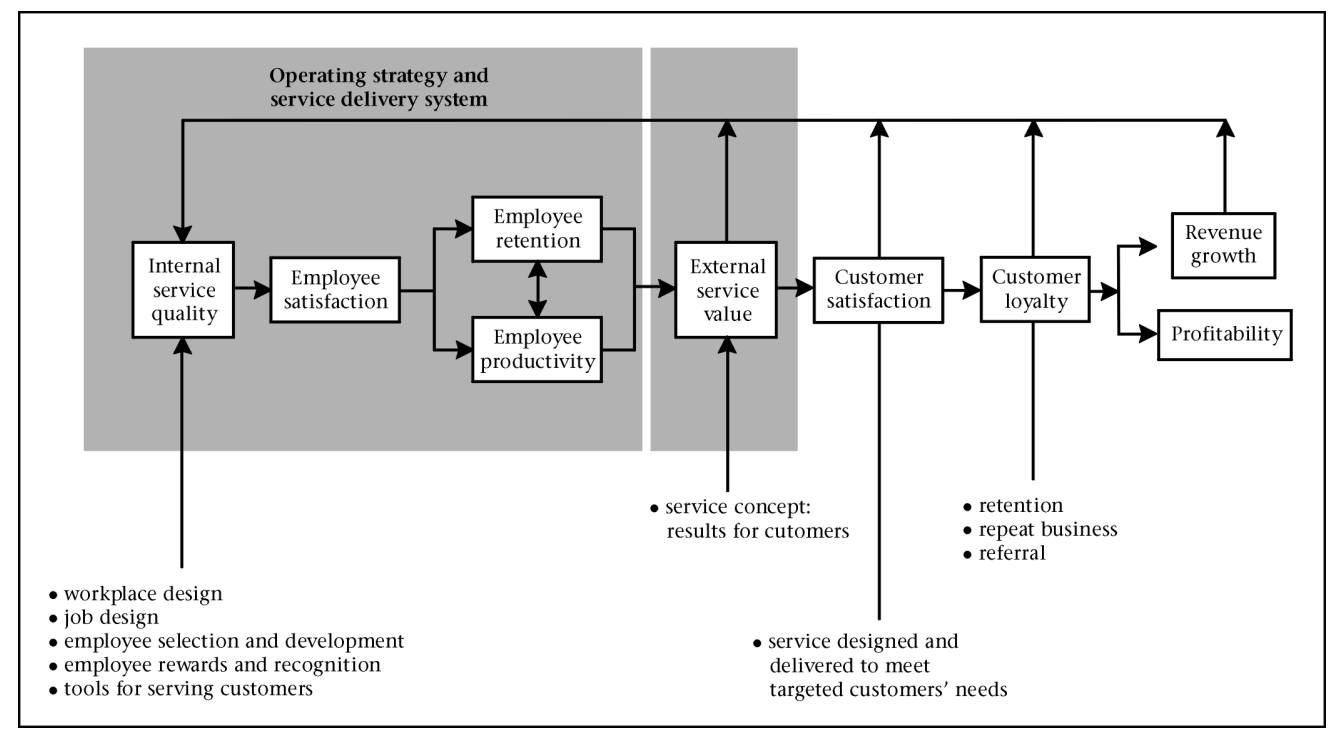

Figure 1: The Links in the Service-Profit Chain (Harvard Business Review, March - April, 1994) 
she investigates why the various organisations are regarded as the best companies to work for. The companies that were listed were Hollard Insurance, Cell C, Vodacom Group, Discovery Health, Deutsche Bank, Investec Bank and HBD Capital Venture. The reason why these companies were included in the list is because of the way in which they manage and deal with employees. Time and money are spent on employees. Training and development and a good working environment appear to be high on the priority list of the management. Thus, work becomes fun and the employees work productively. It is also safe to say that those companies are doing well in the area of economic performance.

Heskett et al (1994); and Herselbein, Goldsmith and Blanchard (1997, p. 35) also bring the concept of customer care and employee satisfaction together in the concept of the "serviceprofit chain". Bearing in mind the link between corporate culture and employee satisfaction, they argue that the role of the employee in the process of customer service should not be underestimated. If you want to keep the customers happy, you need to ensure that the employees are satisfied and that the employment relationship is managed in such a way that it is conducive to the promotion of good customer service, and customer service is a prerequisite for being successful in the international market.

\section{What is corporate culture?}

Schein (1999), explains that the biggest danger in dealing with and understanding culture is to oversimplify it. He regards corporate culture as a multi-level concept that should be analysed at every level before it can be understood. He defines corporate culture $(1999$, p. 24$)$ as "... the learned, shared, tactical assumptions on which people base their daily behaviour".

In line with the thought that culture is multi-levelled, Schein (1999, pp. 25-26) identifies three levels of culture, viz. that "culture is deep" - if you treat it as a superficial phenomenon, if you assume that you can manipulate it and change it at will, you are sure to fail; "culture is broad" - as a group learns to survive in its external and internal relationships; and "culture is stable" - the members of a group want to hold on to their cultural assumptions, because culture provides meaning and makes life predictable.

Sadri \& Lees (2001) see corporate culture as "an intangible concept, it clearly plays a meaningful role in corporations, affecting employees and organisational operations throughout a firm." They go even further and are of the opinion that culture not only determines the success or failure of the organisation, but that a positive culture can be a competitive advantage over competing firms or organisations. In addition to this point of view of Sadri \& Lees (2001), Bliss (1999) believes that corporate culture is very important, since it is the total sum of the values, virtues and accepted behaviours, which includes the good and not so good. Bliss agrees with the viewpoint that the success that the organisation achieves is strongly influenced by its culture.

Ogbor (2001), however, adopts a more cynical approach to corporate culture and to what it is. Contrary to Schein (1999) and Sadri \& Lees (2001), Ogbor sees corporate culture as “... managerial control and a whole-hearted acceptance of the means through which employees in an organisation are repressed." He argues further that corporate culture "... remains an ideology, which is socially constructed to reflect and legitimize the power relations of managerial elites within an organisation and society at large".

Payne (1991), also discusses the issue of corporate culture and, more specifically, "what is corporate culture?". He is of the opinion that it is "... the pattern of all those arrangements, material or behavioural, which have been adopted by a society (corporation, group, team) as the traditional ways of solving problems of its members; culture includes all the institutionalised ways and the implicit cultural beliefs, norms, values and premises which underline and govern behaviour." In his definition of culture he goes further and distinguishes implicit and explicit culture. According to Payne, explicit culture refers to "... typical and distinctive behaviour of people and the typical and distinctive artefacts they produce", and implicit culture refers to the "... total set of cultural beliefs, values, norms and premises which underlies and determines the observed regularities in behaviour making up the explicit culture". It is therefore clear that corporate culture is a very complex issue. It would also appear from the work of Payne that corporate culture impacts on employee satisfaction. This notion is supported by the work of Treacy \& Wiersema (1993) with their concept of the Value Discipline Model, and the work of Heskett et al. (1994) in their Service-Profit Chain Model. These models and the work of Payne will be used to identify the various factors influencing corporate culture, and this will assist in the development of a framework that can provide a strategy for higher education.

Irrespective of what one's point of view on culture is and whether it is positive or negative, the reality is that corporate culture does exist within every organisation, and according to Sadri \& Lees (2001) and Bliss (1999), corporate culture plays a significant role in the success or failure of an organisation and cannot be divorced from the concept of customer service. Wiersema (1998:162) confirms this point of view. He is of the opinion that "... the culture of a customer-intimate company with its distinctive behaviours, beliefs and mind-set - is the single most important underpinning of successfully adopting the customer-intimate discipline."

\section{Proposed model}

Based on the above, the model as set out in Figure 2 can be proposed as a framework for the study and research. This model illustrates the suggested relationship between the variables and how culture and job satisfaction impact on the level of learner satisfaction

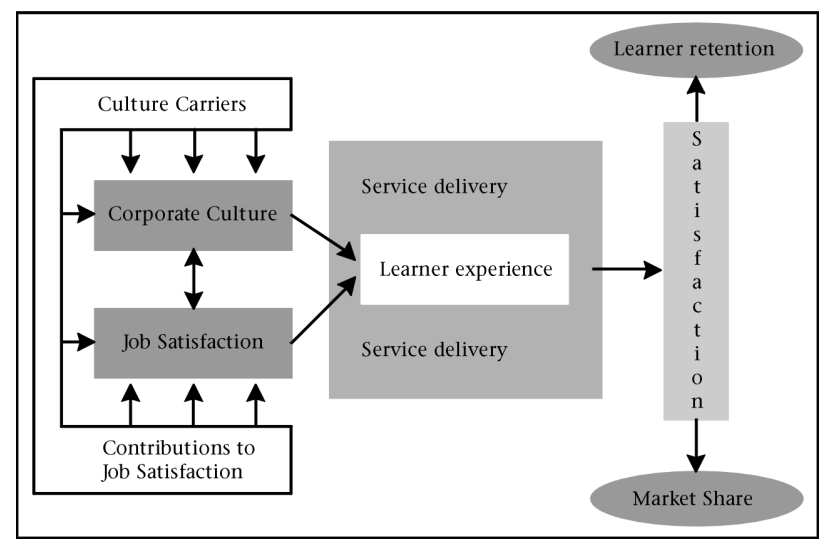

Figure 2: The relationship between corporate culture, job satisfaction and Value of the research

(Higher Education Environment - Technikon Pretoria)

When the study has been completed, there will be a better understanding of the various factors that influence the establishment of a corporate culture that promote the delivery of quality customer service in a higher education environment. As indicated earlier, the position of the higher education institutions has changed, and the Minister of Education and the external environment now demand a different approach.

The focus is ultimately on having the ability to function at a world-class level, being competitive and retaining and expanding market share, as in the case of the private sector. 
With the emphasis on the levels and quality of customer service, an organisation cannot claim that it is functioning on a world-class level and is competitive if it does not make an aggressive attempt to ensure customer service. Customer service is synonymous with world-class. Similar to the private sector, the major ingredient that makes the difference between one organisation and the next is the people within the organisation. The levels of employee satisfaction and the nature of the corporate culture in the organisation do have an impact on the level and the quality of the customer service that is rendered to customers.

Once a better understanding has been created, a strategy can be developed for improving the levels of customer service. This will enable the institutions to meet the expectations and demands of the environment which they function in.

\section{THE AIM OF THE STUDY}

The aim of this study can be summarised as follows:

- To determine the association between corporate culture and employee satisfaction.

- To determine the association between employee and learner satisfaction.

- To establish what the association is between learner satisfaction and corporate culture.

\section{METHOD}

The organisation selected for the study was a large higher education institution. Owing to the limited nature of this study, a non-probability approach was selected. The sample was constituted of the following groups:

- Lecturing employees at the Peromnes post levels 5 to 9 in all faculties.

- Academic Administration employees at the Peromnes post levels 5 to 19.

- Financial Administration employees at the Peromnes post levels 5 to 19 .

- Accommodation and Catering employees at the Peromnes post levels 5 to 19 .

- Student Affairs employees at the Peromnes post levels 5 to 19.

- Library employees at the Peromnes post levels 5 to 19.

- Building and Estates and Logistical Services employees at the Peromnes post levels 5 to 19 .

The reason for selecting this sample was that these groups of employees spent the majority of their day interacting with learners. These employees also represent the majority of the total number of full-time employees and were in the best position to provide an opinion on corporate culture and employee satisfaction. From this group of 1112 employees, a 20\% convenience sample was drawn to participate in the study. The sample was stratified in terms of lecturing/non-lecturing, post level, and faculty/directorate.

The focus was on the senior learners. The learners in this group have adapted to the new higher education environment and are also typically involved in the various organisational structures and leadership bodies available to learners. They also enjoy representation on the Council of the institution; have had the benefit of being part of the higher education experience and should have an informed opinion. A convenience sample was drawn per faculty, stratified according to department, race and gender. The Division for Statistical Support assisted with the sampling plan and the data-capturing process.

\section{Measuring instruments/data gathering}

In this study, three already developed measurement instruments were used. The first instrument focussed on the measurement of corporate culture, the second made an assessment of job satisfaction, and the third and last instrument focussed on the satisfaction levels of learners. The three instruments are discussed below.

\section{Organisational culture measurement instrument}

To assess the organisation's culture, the Organisation Culture Questionnaire (OCQ), as developed by Van der Post, De Coning \& Smit (1997), was used. Van der Post et al. (1997) developed the OCQ by following an extensive process, including a literature review and an evaluation panel consisting of human resource experts. From this process the 15 subdimensions were formulated. The OCQ was also developed in the South African environment. In this study various roles and culture carriers were identified from the literature review that correlated with the subdimensions of the OCQ.

The subdimensions are:

- Conflict resolution

- Culture management

- Customer orientation

- Disposition towards change

- Employee participation

- Clarity of goals

- Human resources orientation

- Identification with the organisation

- Locus of authority

- Management style

- Organisation focus

- Organisation integration

- Performance orientation

- Reward orientation

- Task structure

Based on the studies done by Van der Post et al. (1997), the reliability coefficients for each of the cultural dimensions varied between 0,788 and 0,939 . In the study by Van der Post et al. (1997) in was not possible to employ external criteria to determine the validity of the instrument, however, the construct validity was tested using factor analysis. In terms of validity Van der Post et al. (1997) reported that a high to moderate factor loading on each of the subdimensions were obtained, that is between 0,840 and 0,391 that suggests an acceptable level of construct validity. In a study by Sempane, Reiger and Roodt (2002), the reliability of the OCQ was supported by a Cronbach Coefficient of 0, 987 that was obtained. Thus, the questionnaire appeared to meet the standards of good scientific practice.

In order to facilitate the opinions of the participating employees in the study, a seven-point Likert scale $(1=$ completely disagrees, $2=$ mostly disagrees, $3=$ slightly disagrees, $4=$ undecided, $5=$ slightly agrees, $6=$ mostly agrees, $7=$ completely agrees) was implemented with this questionnaire.

Job satisfaction questionnaire

The questionnaire to be used to determine the level of job satisfaction amongst employees, is a shortened version of the Minnesota Job Satisfaction Questionnaire (MJSQ), developed by Weiss, Dawis, England and Lofquist (1967). The motivation for the use of the MJSQ is to be found in the reported validity of the instrument as reported by Jewell, Beavers, Kirby and Flowers (1990). (The content validity of the instrument was critiqued by a panel of experts). Jewell et al. (1990) also reported a high level of stability in testing and retesting, and Cronbach Alpha Coefficient of 0,89. Bodur (2002) reported that the internal consistency of the questionnaire was 0,849 , obtained by using the Cronbach Alpha Coefficient. In a further study a Cronbach Alpha Coefficient of 0,92 was obtained by Sempane et al. (2002).

This measuring instrument is fairly simple and straightforward. It contained twenty items covering a variety of issues that are related to the work experience. These items included the 
meaningfulness of the task or job ethics, opportunities to utilise abilities and skills, conditions of employment, rewards for performance, management style and team relations.

All items were stated in the positive and were phrased in simple and easily understood language. Respondents were required to record their responses on a five-point Likert scale $(1=$ very dissatisfied, $2=$ dissatisfied, $3=$ not satisfied or dissatisfied, $4=$ satisfied and $5=$ very satisfied)

This questionnaire was submitted to employees with the organisational culture questionnaire, to ensure that the questionnaires did not get lost or mixed up with any other respondent's responses, and to assist with and streamline the surveying process.

\section{Learner satisfaction questionnaire}

This questionnaire had originally been developed in Australia based on qualitative analysis of 60,000 comments written by graduates on Australia's Course Experience Questionnaire. This questionnaire asks respondents to rate the items on importance as well as performance. The instrument is thus a self-validating tool (personal communication with G. Scott, University of Technology Sydney, 2004). According to Scott (2004) research on what engages students in productive learning in post-secondary and higher education indicates that it is the total experience of university, not just what happens in the traditional classroom that influences learning, and the current research done in Australia with successful graduates has confirmed the sub-scales covered in the questionnaire. In addition the Student Satisfaction Survey was benchmarked with a survey used by another Australian University when first administered in 1994 (Scott; 2004). The above information supports the validity of the instrument. The reliability of the instrument as applied to Technikon Pretoria will be tested once the results of the study are obtained.

Through a cooperation agreement between Technikon Pretoria and the Australian Universities of Technology Network (AUTN) a project was initiated to apply the Student Satisfaction Survey (SSS) at Technikon Pretoria. After a limited pilot study was done, the questionnaire was adapted for the South African higher education environment. The only dimension that was added was one relating to the student newspaper, Taxi, which is unique to the learners of Technikon Pretoria (Genis, comments during a personal interview, 3 February 2004).

This and the abovementioned confirms that this questionnaire poses an acceptable level of reliability and validity.

For this study eighty-seven statements, divided into seven subdimensions, were presented to learners. The learners had to respond with regard to the importance of the item and the level of satisfaction (performance). For the purpose of this study the focus was on the level of satisfaction. The following subdimensions were tested:

- Programme quality and content (academic students)

- Outcomes of the study programme

- Administration

- Access to facilities

- Study assistance

- Student services

- General student facilities

- Student Representative Council

- Taxi, a student publication

All items were stated in the positive and were phrased in simple and easily understood language. Respondents were required to record their responses on a five-point Likert scale $(1=$ very dissatisfied, $2=$ dissatisfied, $3=$ not satisfied or dissatisfied, $4=$ satisfied and $5=$ very satisfied).

\section{Reliability analysis}

In order to justify the use of the instruments, reliability analyses were performed. For the culture survey, a Cronbach Alpha
Coefficient of 0,773 was obtained. For the job satisfaction instrument, a Cronbach Alpha Coefficient of 0,91 was obtained, and a Cronbach Alpha Coefficient of 0,978 was obtained for the learner satisfaction instrument. Thus high reliability levels were achieved for all three instruments.

\section{Research methodology}

The identified group (sample) of participants was exposed to the structured questionnaire. The questionnaires were forwarded to the individuals (employees) via the offices of the deans and directors of various faculties and directorates in the institution. With regard to the learners, the questionnaires were distributed via the internal communication systems of the respective faculties.

\section{Statistical analysis}

Keeping in mind that the research problem was to identify cultural issues influencing customer-service culture in a higher education institution, and in order to obtain meaningful results from the data-gathering process, the following statistical analyses were done:

- Descriptive statistics on variables of a quantitative nature in the questionnaire.

- Frequency analyses on questionnaire items to evaluate the corporate culture.

- Rank-order correlations to establish the relationship between culture, employee job satisfaction and learner satisfaction.

\section{RESULTS}

TABLE 1

EMPLOYEE SAMPLE DATA

\begin{tabular}{lccc}
\hline Faculty/Directorate & $\begin{array}{c}\text { Number of } \\
\text { employees in } \\
\text { faculty/ } \\
\text { directorate }\end{array}$ & $\begin{array}{c}\text { Number of } \\
\text { employees } \\
\text { returning the } \\
\text { questionnaire }\end{array}$ & $\%$ \\
\hline Arts Faculty & 85 & 18 & 21 \\
Faculty of Economic Sciences & 82 & 10 & 12 \\
Faculty of Engineering & 97 & 10 & 10,3 \\
Faculty of Social Development Studies & 59 & 8 & 14 \\
Faculty of Natural Sciences & 86 & 14 & 16 \\
Faculty of Agriculture, Horticulture & 52 & 8 & 15 \\
and Nature Conservation & 82 & 14 & 17 \\
Faculty of Health Sciences & 52 & 11 & 21 \\
Faculty of Information and & 595 & 93 & $\mathbf{1 5 , 6}$ \\
Communication Technology & 52 & 16 & 31
\end{tabular}

\section{OPERATIONS}

Buildings and Estates

Accommodation and Catering

Logistical Services

$\begin{array}{ccc}67 & 8 & 12 \\ 42 & 8 & 20 \\ 173 & 53 & 31 \\ 282 & 69 & 25\end{array}$

\section{STUDENT AFFAIRS}

Sport Development

Student Development

Academic Support

Financial Support Bureau

Registrar (Finance)

Registrar (Academic)

Total

\begin{tabular}{lcc}
11 & 2 & 19 \\
11 & 3 & 27 \\
17 & 9 & 52 \\
7 & 4 & 57 \\
46 & 18 & 39 \\
64 & 8 & 39 \\
73 & 22 & 30 \\
112 & 231 & 21 \\
\hline
\end{tabular}

Table 1 indicates employee sample data.

The sample included only the permanent employees at post levels $5-19$ (Peromnes post grading system) who deal directly 
with learners. In this sample, both academic and administrative employees were included. It is important to note that all the faculties are included in the sample.

From Table 1 it should be noted that 231 employees responded of a total of 1112 employees. Of the 595 Academic employees (possible respondents), $93 \quad(15,6 \%)$ returned their questionnaires. Two faculties, the Arts Faculty and the Faculty of Information and Communication Technology, both returned $21 \%$ of their questionnaires, which would be regarded as sufficient. The Faculty of Engineering had the lowest rate, namely $10,3 \%$, while the Faculty of Economic Sciences had a $12 \%$ rate.

The support sections, namely Library Services, Operations, Student Affairs, Finances and Academic Administration, responded well. The lowest response (20\%) came from Finances and the highest response (39\%), came from Student Affairs. Other responses from the Library (31\%) Academic Administration (30\%) and Operations (25\%) contributed the study.

TABLE 2

LEARNER SAMPLE DATA

\begin{tabular}{lccc}
\hline Faculty/Directorate & $\begin{array}{c}\text { Number of } \\
\text { learners in } \\
\text { faculty }\end{array}$ & $\begin{array}{c}\text { Number of } \\
\text { learners } \\
\text { returning the } \\
\text { questionnaire }\end{array}$ & $\%$ \\
\hline Arts & 1572 & 337 & 21,4 \\
Economic Sciences & 5631 & 1275 & 22,6 \\
Engineering & 2838 & 435 & 15,3 \\
Social Development Studies & 2016 & 208 & 10,3 \\
Natural Sciences & 1672 & 519 & 31,0 \\
Agriculture, Horticulture and & 2002 & 44 & 2,1 \\
Nature Conservation & 1487 & 329 & 22,1 \\
Health Sciences & 1883 & 48 & 2,5 \\
Information and Communication & 19101 & 3195 & 16,7 \\
Technology (ICT) & & & \\
Total &
\end{tabular}

Table 2 indicates learner sample data.

The majority of the learners in the various faculties responded well to the study. The outstandingly high responses came from Natural Sciences (31\%), Economic Sciences $(22,6 \%)$, Health Sciences $(22,1 \%)$ and Arts, with a response of $21,4 \%$. Responses obtained from Information and Communications Technology and Agriculture, Horticulture and Nature Conservation, were $2,5 \%$ and $2,1 \%$ respectively.

The average response of the faculties mentioned was $16,7 \%$.

\section{Culture questionnaire results}

Table 3 provides a macro view of how the various subdimensions were rated by the respondents. The subdimensions that were rated the highest were customer orientation, followed by disposition towards change, identification with institution, performance orientation and human resource orientation.

On the lower end of the spectrum, task structure was rated the lowest, followed by locus of authority, management style, conflict resolution and employee participation.
TABLE 3

RANKING OF MEANS OF THE SUBDIMENSION IN CULTURE

\begin{tabular}{lc}
\hline Culture subdimension & Ranked per mean \\
\hline Customer orientation & 5,26 \\
Disposition towards change & 4,90 \\
Identification with the organisation & 4,77 \\
Performance orientation & 4,75 \\
Human resource orientation & 4,59 \\
Culture management & 4,53 \\
Organisational focus & 4,52 \\
Organisation integration & 4,38 \\
Clarity of goals & 4,27 \\
Reward orientation & 4,24 \\
Employee participation & 4,21 \\
Conflict resolution & 4,17 \\
Management style & 4,06 \\
Locus of authority & 4,01 \\
Task structure & 3,57 \\
\hline
\end{tabular}

TABLE 4

JOB SATISFACTION PERCENTAGES

\begin{tabular}{lc}
\hline ITEM & Percentages \\
\hline Being able to keep busy all the time & 82.3 \\
The chance to work alone on the job & 81.4 \\
The chance to do different things from time to time & 75.4 \\
The chance to be “somebody" in the community & 68 \\
The way my senior handles his/her staff members & 63.3 \\
The competence of my supervisor in making decisions & 61.4 \\
Being able to do things that don't go against my conscience & 71.5 \\
The way my job provides for steady employment & 79.4 \\
The chance to do tings for other people & 81.1 \\
The chance to tell people what to do & 66.3 \\
The chance to do something that makes use of my abilities & 74.6 \\
The way company policies are put int practice & 55.9 \\
My pay and the amount of work I do & 44.5 \\
The chances for advancement on this job & 38.7 \\
The freedom to use my own judgement & 60.5 \\
The chance to try my own methods of doing the job & 65.4 \\
The working conditions & 60 \\
\hline & 63.8 \\
The way my co-workers get along with each other & 58.9 \\
\hline
\end{tabular}

Results for the Job Satisfaction questionnaire are shown in Table 4 .

The strengths were: being busy all the time $(82 \%)$, the chance to work alone $(81,4 \%)$, the chance to do things for others $(81,1 \%)$ and the job provides steady employment (79\%). The weaknesses were: the way company policies are put in to practice $(55,9 \%)$, my pay and the amount of work I do $(44,5 \%)$, chances of advancement on the job $(38,7 \%)$ and the amount of praise people get for doing a good job (58\%). 
TABLE 5

RANKED MEANS SCORES FOR THE LEARNER SATISFACTION QUESTIONNAIRE

\begin{tabular}{lc}
\hline Subdimension & $\begin{array}{c}\text { Ranked means scores } \\
\text { for the learner } \\
\text { satisfaction questionnaire }\end{array}$ \\
\hline Outcome of studies & $3,68^{*}$ \\
Academic programme & 3,62 \\
Access and study assistance & 3,44 \\
Taxi & 3,37 \\
Administration & 3,31 \\
Student services & 3,31 \\
General facilities & 3,18 \\
SRC & 2,83 \\
\hline
\end{tabular}

$\left({ }^{*}\right.$ Likert scale of 1-5 was used here)

Table 5 shows learner satisfaction results.

The strengths were (based on a Likert scale of 1-5): outcome of studies $(3,69)$, academic programme $(3,62)$ and access and study assistance $(3,44)$. The areas of weaknesses were: administration $(3,32)$, student services $(3,32)$, general facilities $(3,19)$ and Student Representative Council $(2,84)$. From a learner perspective, the SRC achieved the the lowest level of satisfaction.

TABLE 6

RANK ORDER CORRELATION MATRIX: CULTURE X JOB SATISFACTION $X$ LEARNER SATISFACTION

\begin{tabular}{lccc}
\hline & Culture & Job satisfaction & Learner satisfaction \\
\hline Culture & 1 & 0,07 & 0,43 \\
Job satisfaction & - & 1 & $-0,05$ \\
Learner satisfaction & - & - & 1 \\
\hline
\end{tabular}

Table 6 indicates the relationship between organisational culture, job satisfaction and learner satisfaction.

Not all of the departments could be used for the rank order correlations, because data was not available for the learners (operational departments). However, the eight academic faculties could be compared, and eight pairs were acceptable for the rank order correlation.

An examination of the results showed that there were no significant correlations between the variables at the significance level $\mathrm{p}<0.10$ However, the correlation between culture and learner satisfaction approached significance.

\section{DISCUSSION}

The results did not support a relationship between the culture and job satisfaction. In view of the literature that had been studied, a strong relationship between corporate culture and job satisfaction could be expected.

The relationship between culture and learner satisfaction was not significant, but there was a much strong tendency displayed. This tendency might be explained by the fact that the institution places a high premium on quality service delivery to learners and that the learners are important to the institution. Customer orientation was the dimension in the questionnaire that received the highest rating.
The relationship between staff job satisfaction and learner satisfaction also did not approach significance. In view of the Service-Profit Chain model, it could have been expected that a significant relationship would exist between job satisfaction and customer (learner) satisfaction.

Bearing in mind these results, the model developed by the authors was subjected to an evaluation. Firstly, positive factors which could influence the relationships between culture, employee satisfaction and learners satisfaction and ultimately learner retention were assessed, and an attempt was made to explain the results.

Figure 3a suggests that cultural strengths such as a strong customer orientation, a strong disposition to change, a strong identification with the organisation, a strong performance orientation, and human resource orientation might have related to higher levels of learner satisfaction found in the areas of outcome of studies, academic programme and access to study assistance. The culture factors appear to be essentially "outward looking" and could also be related to enhanced learner retention and market share.

Strengths identified in the employee job satisfaction area eg, being busy all the time, the chance to work alone, the chance to do thing for others, and steady employment appear to be mostly "inward looking", and perhaps not related to learner satisfaction, and with the broader culture issues within the organisation.

Secondly, figure 3b examines weaknesses within corporate culture, employee job satisfaction, and learners satisfaction. Culture weaknesses discovered were: less satisfaction with management style, locus of authority, task structure, conflict resolution, and employee participation. These negative aspects could relate to weaker service delivery issues expressed by learners such as dissatisfaction with the general facilities, the SRC, student services, and administration.

As previously suggested, the culture issues appear to be "outward looking", thus possibly relating to learner satisfaction and retention. Areas of staff dissatisfaction lay in chances for advancement, poor pay and heavy work load, the way company policies were put in practice and the amount of praise people received for doing a good job. These appear to be "inward looking" and not related to broader culture and learner satisfaction issues.

It seems, on reflection that, the relationship and interaction between the lecturers (employees) and the learners (customers) may not be the same as in the case of the normal business environment. The learner is not only the customer, but also the "product", suggesting that there could be leadership and mentoring relationships that bring a new dimension to the delivery of pure customer service. It would also seem that employees and learners did not move in the same circles and employees obtained their satisfaction from different things than learners.

The results suggested that the culture of the institution is one where the customer is perceived to be important. Excellence was important and people knew what they had to do to be successful, but with this strong focus on performance, other aspects that would promote a stronger culture might have been weakened, such as worker participation, reward orientation, management style and conflict resolution. The relationship between the employees and learners could be developed more. That should contribute to the enhancement of learner satisfaction and retention. 


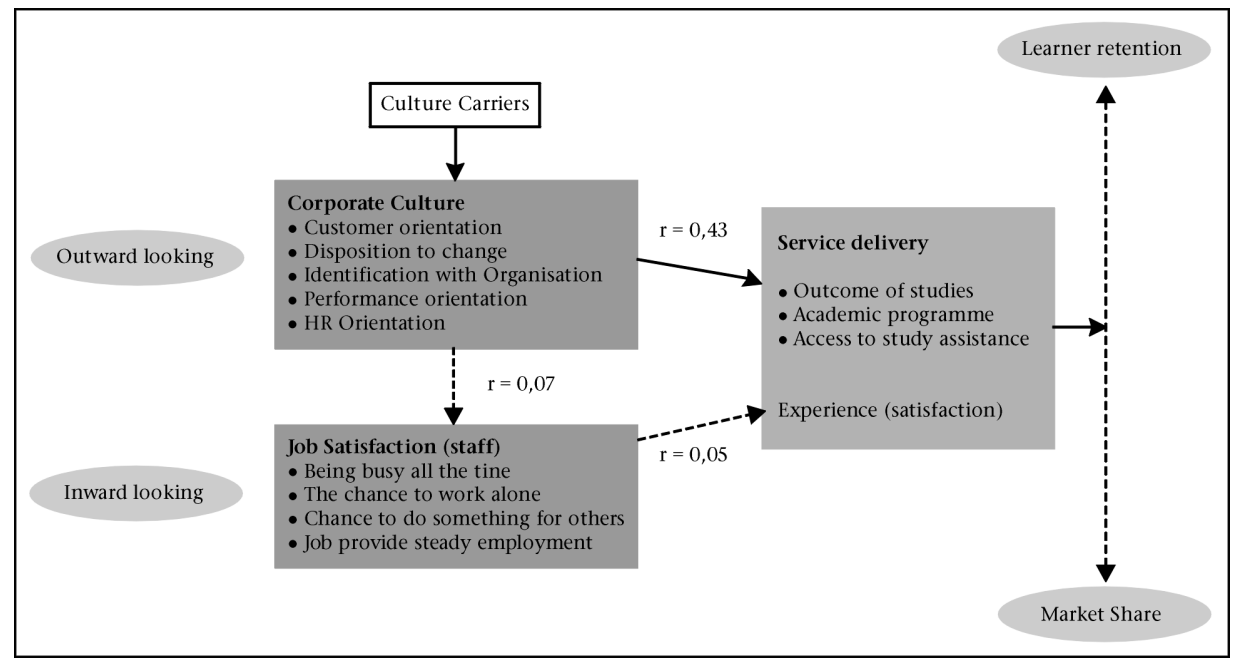

Figure 3a: The Learner Satisfaction Model - Corporate Strengths

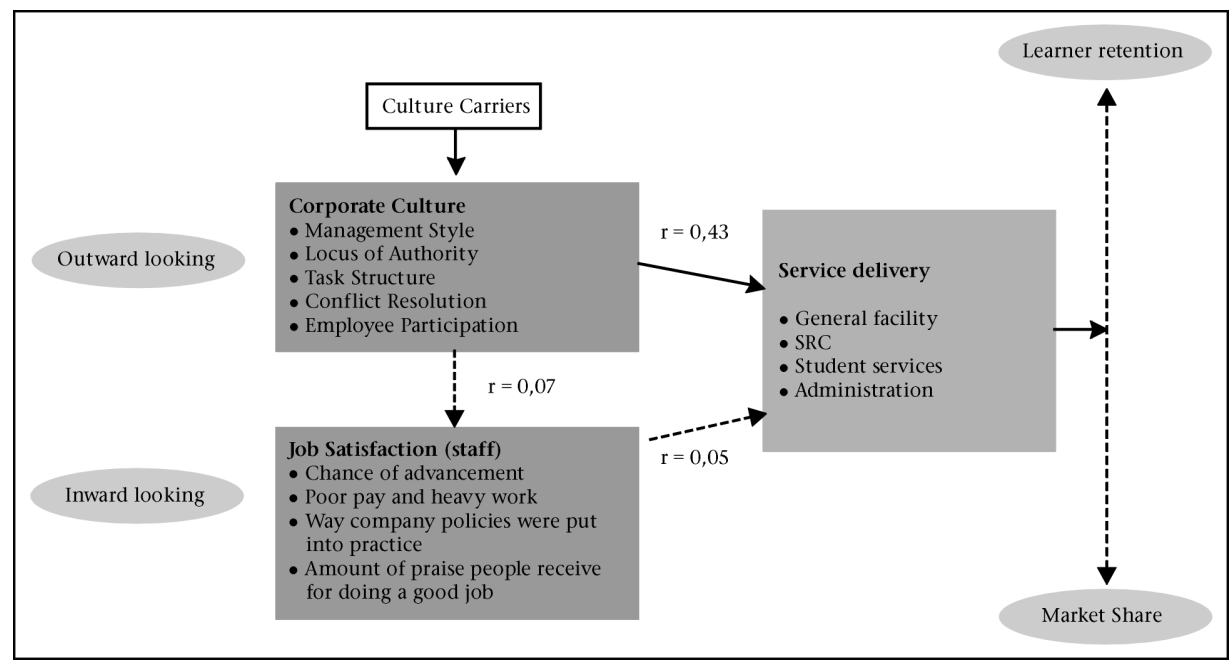

Figure 3b: The Learner Satisfaction Model - Corporate Weaknesses

\section{REFERENCES}

Annual Report of the Council on Higher Education for 1998/1999: (1999). Pretoria.

Bliss, W.G. (1999). Why corporate culture is important. Workforce Extra, February, 8-9.

Bodur, S. (2002). Job satisfaction of health care staff employed at health centres in Turkey. Society of Occupational Medicine, 52 (6), 353-355.

Cheales, P. (1994). Your survival kit for world class customer delight. Struik Publishers South Africa.

Cosser, M. \& Du Toit, J. (2002). Student Choice Behaviour Project: Phase One. Pretoria: HSRC.

Dannhauser, Z. \& Roodt, G. (2001). Value discipline: Measuring customer preferences. Industrial Psychology, 27 (1).

Gitomer, J.H. (1998). Customer satisfaction is worthless, customer loyalty is priceless. Texas: Bard Press.

Grant-Marshall, S. (2002). Companies to die for, Style Magazine, September, 32-38.

Gubman, E.L. (1995). Aligning people strategies with customer values, Compensation \& Benefits Review, January/February, 15-22.

Herselbein. F., Goldsmith, M. \& Blanchard, R. (1997). The organisation of the future. San Francisco: Jossey-Boss Publishers.

Heskett, J.L., Jones, T.O., Loveman, G.W.,Sasser, W.E. \& Schlesinger, L.A. (1994). Putting the Service-Profit Chain to work, Harvard Business Review, March/April.

Higher Education Act, 1997 (Act No.101 of 1997) (as amended). Government Gazette. Pretoria.
Hodgetts, R.M., Luthaus, F. \& Lu, D.M. (1994). New paradigm organisations: from total quality to learning to world-class, Organizational Dynamics, 22 (3), 5-19.

Jewell, J.R., Beavers, K.C., Kirby, B.J.M. \& Flowers, J.L. (1990). Relationships between levels of job satisfaction expressed by North Carolina Vocational Agriculture and their perception towards the Agricultural Education Teaching Profession, Journal of Agricultural Education, Spring, 51-57.

National Work Groups: Report on Higher Education, Department of Higher Education, February 2002.

Ogbor, J.O. (2001). Critical theory and the Hegenomy of corporate culture, The Journal of Organisational Change Management, 14 (6), 590-608.

Olson, J. (1990). Competing in world-class manufacturing: America's $21^{\text {st }}$ century challenge. Hanewood, USA: Business One Irvan.

Payne, R.L. (1991). Taking Stock of Corporate Culture, Personnel Management, July, 26-29.

Peters, T. (1988). Restoring American competitiveness: Looking for new models of organisations. TAC Communications, USA.

Sadri, G. \& Lees, B. (2001). Developing corporate culture as a competitive advantage, The Journal of Management Development, 20 (10), 853-859.

Schein, E.H. (1999). Corporate culture: Survival guide. San Francisco: Jossey-Boss Inc. Publishers.

Scott, G. (2004). Student satisfaction survey, UTS.

Sempane, M.E., Reiger, H.S. \& Roodt, G. (2002). Job satisfaction in relation to organisational culture, SA Journal of Industrial Psychology, 2002, 28 (2), 23-30. 
Slabbert J.A., Prinsloo J.J., Swanepoel, B.J. \& Backer, W. (1998). Managing employment relations in South Africa. South Africa: Butterworths.

Steudel, H.J. \& Desruelle, P. (1992). Manufacturing in the nineties: How to become a mean, lean, world-class competitor. New York: Van Nostrand.

Tersine, R., Harvey, M. \& Buckley, M. (1997). Shifting organizational paradigms: Transitional management, European Management Journal, 15 (1), January, 46-49.

Treacy, M. \& Wiersema, F. (1993). Customer intimacy and other value disciplines, Harvard Business Review, January/February, 84-93.
Van der Post, W.Z., De Coning, T.J. \& Smit, E. (1997). An instrument to measure organisational culture, South African Journal for Business Management, 28 (4).

Verespy, M.A. (1990). World-class organisations: Where people come first, Industry Week, July, 22-28.

Weiss, D.J., Dawis, R.V., England, G.W. \& Lofquist, L.H. (1967), Mannual for Minnesota Satisfaction Questionnaire. Minneapolis: University of Minnesota.

Wiersema, F. (1998). Customer intimacy: Pick your partners, shape your culture, win together. London: Harper Collins Publishers. 